\title{
Social Capital and Career Success in Learning Geography Education among Students of Tertiary Institutions in Katsina State, Nigeria
}

\author{
AminuRilwanu and BuhariAbdulkarim \\ Department of Geography, Isa Kaita College of Education, PMB. 5007, Dutsinma, Katsina State, Nigeria
}

\begin{abstract}
Social capital creation is necessary in any development; as such the research work was designed to explore the role of social capital and career success in learning geography education among students of tertiary institutions in Katsina state, Nigeria. Objective of the research was designed to determine the relationship between social capital and career success in learning geography education, to describe the level of social capital and career success in learning geography education. The study use simple random sampling in selecting the potential respondents. Pearson correlation analysis was used to determine the relationship between social capital and career success, descriptive statistics was also employed to describe the levels of social capital in relation to career success in learning geography and lastly cross tabulation was also used. Results of the findings shown that, there is significant positive relationship between social capital and career success in learning geography education $(r=.416, p=.000)$. Results from descriptive statistics indicated that, majority of the respondents were in high level of social capital creation. Meanwhile, cross tabulation results shown that, majority achieved high in social capital and career success in learning geography education among students of tertiary institutions in Katsina state, Nigeria.
\end{abstract}

(Key words: Social capital, Career success and Geography education)

\section{Introduction}

This study needs to provide some basic considerable determinants of social capital and career success in the academicfield of learning Geography education among the students of tertiary institutions in Katsina state, Nigeria (Judge \&Bretz, 1994; Pfeffer, 1978). Popular advice for "getting ahead" in one's career rarely fails to mention the importance of "networking" for achievement of career goals to students and teachers as well, in all the tertiary institutions (e.g., Bolles, 1992; Huang, 2005). Indeed, Luthans, Hodgetts, and Rosenkrantz (1988) found that the most successful learning process through networking spent 70 percent more time engaged in social networking activities and 30 percent more time in routine activities than their less successful counterparts. Recent advances in social capital theory (Coleman, 1990) have begun to provide a more fine-grained analysis of the ways students' social networks affect their career success in the field of learning (Burt, 1992, 1997; Ibarra, 1995; Sparrowe\&Popielarz, 1995; Podolny\& Baron, 1997; Ng, et al. 2005). This theoretical perspective has the potential to a considerable extent that success in learning is strongly connected with social networking among the students in the tertiary institutions.

This study tries to provide integration on current conceptualizations of social capital as they pertain to career success in learning geography education among students of tertiary institutions in Katsina state, Nigeria. In due course three different theoretical approaches were reviewed, the weak tie theory (Granovetter, 1973; Cross and Cumming, 2004), structural holes theory (Burt, 2001), and social resource theory (Lin, 1990). All the afore-mentioned theoriesfocus on different network properties as representations of social capital towards students career success in learning geography. However, all thethree theories have contributed significantly to career success in the body of learning process and helps in providing clear explanationon social capital and career success. Students' mobility (like educational excursion, field trip and side seeing) are greateraccess to information, resources, and social credentialed. The main contribution of the current study is to explore the relationship between social capital and student career success in learning, especially geography education.

The research work consider the student extrinsic and intrinsic behaviors in learning process, used as measures of career success (e.g., Judge \&Bretz, 1994; Judge, et al., 1995; Hall, 2002; Seibert, Crant, \&Kraimer, 1999; Turban \& Dougherty, 1994; Wayne, Liden, Kraimer, \& Graf, 1999; Mehra, Kilduff,\& Brass, 2001).

- The extrinsic behavior of studentscareer success/outcomes are objectively observed such as student performance and participation in class, class assignment, test, field trip and laboratory work and any other academic activities. 
- While the intrinsic student career success refers to the individual's subjective feelings of accomplishment and satisfaction with his or her learning environment, student teacher relationship, teacher methodology in teaching, peer group and availability of learning facilities (London \&Stumpf, 1982).

Some scholars argued that, the extrinsic and intrinsic factors are related, although they have a distinct constructs (Aryee, Chay, \& Tan, 1994; Heslin, 2005; Wayne et al., 1999) and both are important because they can reflect not only to a conventional standards of measuring students success, but student individual feelings as well as student goals and expectations (Judge \&Bretz, 1994; Judge et al., 1995; London \&Stumpf, 1982; Seibert et al., 1999). Linking social capital and career success,somescholars have provided a rigorous demonstration on the role of social capital in career success.

This study has tries to integrate the knowledge in social network structure with the literature on mentoring relationship and careers success. Mentoring has been defined as a developmental relationship in which a less experienced organizational member receives help and guidance from a more experienced member with the aim of improving the career opportunities and growth of others (Kram, 1985). Research has explored the origin and progress of mentor relationships and the types of activities taking place within the mentor protégé relationship (e.g., Chao et al, 1992; Noe, 1988; Turban \& Dougherty, 1994). The literature has also emphasized on the important benefit that mentor may have on one's career success (e.g., Dreher\& Ash, 1990; Katz, 1994). Kram (1985) has suggested that it is important to understand the full constellation of developmental relationships in which a protégé can be involved.

However, some research has explored the simultaneous impact of multiple developmental contacts in social capital, the way in which the organizational location of these developmental contacts effects their contribution to career success. Lastly how the structure of one's social network facilitates access to career success in relation to students' learning in tertiary institutions.Dreher\& Ash, (1990) Social capital literatures explore to what extend the mentoring relationship may specify the types of network structures that are likely to provide/create among the students in tertiary institution for career success in their learning and academic activities. The most important career success student is looking for is not more than to excel in all his/her academic per sue. At the same time the social capital literature is trying to enhance the student success when it was well planned and executed. The research work begins with a review of the theories and literatures related with social capital and career success in the body of learning among the students of tertiary institutions in Katsina state, Nigeria.

\section{Reviewed Theories of Social Capital}

Coleman (1990) defined social capital as any aspect of social structure that creates value and facilitates learning actions among studentswithin theacademic environment. Just as the creation of physical capital involves changes in materials so as to facilitate good learning condition, and human capital involves changes in an individual's skills, knowledge acquisition and capabilities/confidence. While, social capital is created when the relations among students change in ways that facilitate learning and instrumental action (Coleman, 1990; Podsakoff, et al. 2003). Social network researchers have taken in formalizing and empirically testing theories related to the concept of social capital. Social network researchers regard relationships as "ties", the basic data for analysis. A "network" can be defined as the pattern of ties linking a defined set of persons or social actors. Each student can be described in terms of his or her linkages with other student in the network. The focal person in such an analysis is referred to as "ego" (who is usually the person supplying the data/information during academic discussion) while otherstudents that are learning under him or hercan be referred as "alters" (Knoke\&Kuklinski, 1982).

The first approach to the conceptualization of social capital theory, (Granovetter, 1973), focuses on the strength of the social tie used by a person in the process of finding a job. Granovetter(1973) argued that ties among members of a social clique are likely to be strong (defined as emotionally intense, frequent, and involving multiple types of relationships such as friendship, advice) to coworker or students clique. The knowledge possessed by any one of the students among theclique is likely to be either shared quickly or already redundant for other students.Granovetter (1973)defined weak ties as a bridge between densely interconnected students and thus provide a source ofunique knowledge and resources for effective learning. Indeed, Cross and Cumming, (2004) found that weak ties were more likelythan strong ties to have been the source of information about job openings for the sample of jobincumbents he interviewed. Subsequent research has provided mixed support for the weak tiehypothesis (Bridges \&Villemez, 1986; McPherson, Popielarz\&Drobnic, 1992; Murray, Rankin \&Magill, 1981).

Burt's (2001) comes up with structural holes approach theory to social capital focuses not on the characteristics of ego'sdirect ties, but on the pattern of relations among alters in ego's social network. That is not direct on the student focal person (ego), but among alters (students) who are learning direct from the ego's source of information. A structural hole issaid to exist between two alters who are not connected to each other. 
According to structural holestheory, it is advantageous for ego (focal person)to be connected to many alters who are themselves unconnected tothe other alters in ego's network. According to Burt's theory (1997, 2001), networks rich in structuralholes provide ego with three primary benefits: more unique and timely access to information, greaterlearningability and control over the available resources within the academic environment, and greater visibility and careeropportunities for ego throughout the social system.

The third major theoretical approach to the conceptualization of social capital is social resourcestheory (e.g., Lin, Ensel\& Vaughn 1981a; 1981b). Social resources theory focuses on the nature of the resources embedded within the network. Lin et al. (1981a) argued that it is not the weakness of the tie per se that conveys advantage nor by extension, it is a bridging property of weak ties.But the fact was that, such ties are more likely to reach someone with the type of resource required for ego to fulfill his or her instrumental objectives. For example in an academic environment, resources like good learning environment is needed (classes, laboratories, library, qualified resource personals (lecturers), well equipped weather station, advantage for executing geographical excursion, field trip, market survey and other side seeing activities). Institutions' that possesses all these resources is more capable for the attainment of better learning geography education then the rest of the ego's and altersrelationship. The researcher here wanted to draw some of the reason that attracts his attention to carried out this research work.

\section{Problem statement}

The research was able to observe that, there is continuous decline of students' performance in learning geography education in Katsina state, Nigeria. As such the research work was designed to find out if there is any relationship between social capital and career success in learning geography education among the students of tertiary education in Katsina state, Nigeria.

\section{Research Objectives}

The researcher was able to draw some objective to achieve at the end of this study:

- To determine the relationship between social capital and career success in learning geography education.

- To describe the level at which social capital can give high achievement of career success in learning geography education.

\section{Methodology}

The researcher used the sample size of 240 respondents, randomly selected by using simple random sampling techniques. The respondents were selected from all the tertiary institution in the state (such as: Federal University Dutsinma, Umaru Musa Yar'adua University Katsina, Hassan Usman Katsina Polytechnics, Federal College of Education Katsina, Isa Kaita College of Education Dutsinma, College of Legal and Islamic Studies Daura, School of Nursing Katsina, Health Technology Daura, Health Technology Kankia, School of Midwifery Malumfashi, College of Administration Funtua, School of Basic and Remedial Studies Funtua). The respondents were selected proportionately from each tertiary institution to avoid biasness. The study was approach quantitatively by using the structured questionnaire in the process of data collection. The researcher used descriptive and correlation statistics in data analysis.

\section{Results Findings and Discussion}

Objective one above indicated that, the research will determine the relationship between social capital and career success in learning geography education.

Hypothesis shown: there is no significant relationship between social capital and career success in learning geography education.

Pearson correlation analysis was conducted to examine the relationship between social capital and career success in learning geography education. Results shown that there is significant positive relationship between social capital and career success in learning geography education among the respondents (students) in tertiary institutions ( $\mathrm{r}$ $=.416, p=.000)$. Therefore, the null hypothesis was rejected.

Level of social capital and career success in learning geography education

Table 1: Levels of Social Capital among the respondents (students) $(n=240)$

\begin{tabular}{|c|c|c|c|c|}
\hline Variable & $\mathbf{N}$ & $\%$ & Mean & SD \\
\hline Social Capital & & & 32.99 & 5.86 \\
\hline Low(13-26) & 14 & 5.8 & & \\
\hline Moderate(26.1-39) & 21 & 8.8 & & \\
\hline $\operatorname{High}(39.1-52)$ & 205 & 85.4 & & \\
\hline
\end{tabular}


Table 1: above shownthe levels of social capital among the respondents (students in tertiary institutions) based on low, moderate and high. The data analysis shown that 205(85.4\%) reflect the high level of social capital achievement among the respondents. And the scores of $21(8.8 \%)$ indicate the moderate level of social capital. Moreover the sum of $14(5.8 \%)$ reflect low level of social capital among the respondents. But the findings had shown that students who obtained high level of social capital were the majority. This reflects that students achieve maximally in career success and learning geography education due to the level of social capital (like academic networking) among the social clique. Considering the total mean is 32.99 and $\mathrm{SD}=5.86$.

Table 2:social capital and career success in learning Geography among students of tertiary institutions

\begin{tabular}{|c|c|c|c|c|c|c|c|c|}
\hline \multirow{3}{*}{$\begin{array}{l}\text { Variable } \\
\text { Social Capital }\end{array}$} & \multicolumn{6}{|c|}{$\begin{array}{l}\text { Levels of Career Success in learning Geography } \\
\text { Education among students in tertiary institutions }\end{array}$} & \multirow{2}{*}{\multicolumn{2}{|c|}{ Total }} \\
\hline & \multicolumn{2}{|c|}{ Low(13-26) } & \multicolumn{2}{|c|}{ Moderate(26.1-39) } & \multicolumn{2}{|c|}{$\operatorname{High}(39.1-52)$} & & \\
\hline & $\mathrm{N}$ & $\%$ & $\mathrm{~N}$ & $\%$ & $\mathrm{~N}$ & $\%$ & $\mathrm{~N}$ & $\%$ \\
\hline $\begin{array}{l}\text { Low(13-26) } \\
\text { Moderate(26.1-39) } \\
\text { High(39.1-52) }\end{array}$ & $\begin{array}{l}1 \\
2 \\
11\end{array}$ & $\begin{array}{r}7.1 \\
14.3 \\
78.6\end{array}$ & $\begin{array}{l}2 \\
8 \\
11\end{array}$ & $\begin{array}{r}9.5 \\
38.0 \\
52.5\end{array}$ & $\begin{array}{l}17 \\
20 \\
168\end{array}$ & $\begin{array}{l}8.3 \\
9.7 \\
82.0\end{array}$ & $\begin{array}{l}21 \\
29 \\
190\end{array}$ & $\begin{array}{l}8.8 \\
12.1 \\
79.1\end{array}$ \\
\hline Total & 14 & $100 \%$ & 21 & $100 \%$ & 205 & $100 \%$ & 240 & $100 \%$ \\
\hline
\end{tabular}

Table 2 above illustrated that, the data collected from the field can also be further simplified in to lowlow category, low-moderate, and low high category for critical observation. Therefore, cross tabulation analysis was done and the results indicated that, the students with low-low level of achievement in social capital has the frequency of $1(7.1 \%)$ and the low-moderate level is $2(14.3 \%)$ among the respondent. Meanwhile,students that achievedlow-high level in social capital had the frequency of 11(78.6\%). This indicated that even among the low level category there are some respondents that fall within the low-low categoryin learning geography education among students of tertiary institutions in the state. Similarly,cross tabulation analysis further shown that in the moderate levels, some students has low-moderate range of $2(9.5 \%)$ level of achievement in learning geography due to social capital created. Some students had the moderate-moderate level of achievement with $8(38 \%)$ and high-moderate category with $11(52.5 \%)$ level of achievement among the respondents. Finally, the high level of career success in learning geography was also classified in to three categories, we have the lowhigh of $17(8.3 \%)$ and moderate-high with $20(9.7 \%)$ then high-high with $168(82 \%)$. Table 2 above has simplified the results analysis from the data collected in the field among the respondents based on social capital creation and career success in learning geography education among students of tertiary institutionsin Katsina state, Nigeria.

Table 2 above in the last column it indicated total social capital and career success, the results analysisindicated that, the total summation for social capital under low category has the frequency of $21(8.8 \%)$ which indicated the low level in social capital and career success in learning geography education among the respondents (students). While, the sum of 29(12.1\%) emerged as moderate level of achievement of career success in learning geography education and 190(79.1\%) indicated the high level of career success in learning geography education among students of tertiary institutions in Katsina state, Nigeria. This study was supported by work of Yi-Ning Katherine Chen, (2011) in his research work on social capital, human capital and career success in public relations in Taiwan. The results finding shown that, there is significant positive relationship between social capital, human capital and career success in public relations in Taiwan. Moreover, Aminu et al. (2014) opined that participation has a significant effects on empowerment through social capital $(\mathrm{z}=4.115, \mathrm{p}=$ $.000)$.

\section{Summary and Conclusion}

Results from this study indicated that,social capital is significantly correlated with students career success in learning geography education with $(\mathrm{r}=.416, \mathrm{p}=.000)$. Moreover, the descriptive analysis indicated that, social capital can leads to career success in learning geography at tertiary institution. The result shown that $21(8.8 \%)$ is low level in social capital creation and career success, while $29(12.1 \%)$ is the moderate level of social capital creation and career success in learning geography education. Moreover, 190(79.1\%) emerges as high level of social capital creation and career success in learning geography education among students of tertiary education in Katsina State, Nigeria.

\section{Recommendations}

- The author of the current study recommend that, the subsequent research can explore the relationship between physical capital and career success in learning geography among students of tertiary institutions. 
- The researcher is recommending that, students should be encourage in group activities like academic discussion, group assignment, organizing educational trip and so on. This can boost in their level of social capital and career success in learning.

- Teachers in tertiary institution should try to create social capital (students-teacher relationship) for easy transfer of knowledge, in order to fill in the structural holes/gap between them.

\section{References}

[1] Aminu, R. Redzuan, Ma'rof Abu-Samah, Asnarulkhadi. (2014). Mediation Effect of SocialCapital in the relationship between Participation and Empowerment among Members offadama User Groups (FUGs) in Kankara Local Community, Katsina State, Nigeria. International Journal of Humanities and Social Sciences Invention. ISSN:2319-7722. Vol.3, Issue 3. Pp. 27-32

[2] Aryee, S. R., Chay, Y. W. \& Tan, H. H. (1994). An Examination of the Antecedents of Subjective Career Success Among a Managerial Sample in Singapore. Human Relations, Vol.47: 487- 509.

[3] Burt, R. S. (1997). The Contingent Value of Social Capital.Journal of Administrative ScienceQuarterly, 42: $339-365$.

[4] Burt, R.S. (2001). "Structural Holes versus Network Closure as Social Capital" in Social Capital:Theory and Research, edited by Nan Lin, Karen S. Cook and R.S. Burt. Aldine de Gruyter.

[5] Bridges, W.R. and Villemez, R. (1986).Helping People Develop their Community. Lexington: University of Kentucky.

[6] Coleman, J. S. (1990).Foundations of Social Theory. Cambridge, MA: Harvard University Press.

[7] Chao, G., Walz, P., \& Gardner, P. (1992). Formal and Informal Mentorships: A Comparison on Mentoring Functions and Contrast with non-mentored Counterparts. Personnel Psychology, Vol.45: 619- 636.

[8] Cross R. and Cumming, J.N. (2004). "Tie and Network Correlates of Individual PerformanceinKnowledge-Intensive Work", Academy of Management Journal. 7, 6 928-937.

[9] Dreher, G. F., \& Ash, R. A. (1990). A Comparative Study of Mentoring Among Men and Women in Managerial, Professional, and Technical Positions.Journal of Applied Psychology, 75: 539-546.

[10] Granovetter, M. S. (1973). "The Strength of Weak Ties," American Journal of Sociology (78:6)., May 1973, pp 1360-1380.

[11] Heslin, P.A. (2005). Conceptualization and evaluating career success.Journal ofOrganizationalBehavior, 26, $113-136$.

[12] Hall, D.T. (2002). Careers in and out of organizations. Thousand Oaks, CA: Sage

[13] Huang, L.L. (2005). Interpersonal harmony and interpersonal conflict.InK.S. Yang,K.K.Hwang, \&Z.F. Yang (Eds.), Indigenous psychological research in Chinese societies(pp. 521-566). Taipei, Taiwan: Yuan-Liou Publishing Company (in Chinese).

[14] Ibarra, H. (1995). Race, Opportunity, and Diversity in Social Circles and Managerial Networks.Academy of Management Journal, 38: 673-703.

[15] Judge, T. A., \&Bretz, R. D. (1994).Political Influence Behavior and Career Success.Journal of Management, $20: 43-65$.

[16] Judge, T. A., Cable, D. M., Boudreau, J. W. \&Bretz, R. D. (1995). An Empirical Investigation of the Predictors of Executive Career Success.Personnel Psychology, 48: 485-519.

[17] Katz, J.S. (1994). "Geographical Proximity of Scientific Collaboration", Scientometrics.31, 1,31-43.

[18] Knoke, D. \&Kuklinski, J. H. (1982). Network Analysis.Sage University Paper series on Quantitative Applications in the Social Sciences, 07-028. Beverly Hills, CA: Sage.

[19] Kram, K. E. (1985). Mentoring at Work: Developmental Relationships in Organizational Life. Glenview, IL: Scott, Foresman, \& Company

[20] Kraimer, M. L., Seibert, S., and Liden, R. C. (1999). Psychological empowerment as aMultidimensional construct: A test of construct validity. Educational andPsychological Measurement,59:127-142

[21] Lin, N. (1990). Social Resources and Social Mobility: A Structural Theory of Status Attainment. In R. L. Breiger (ed.)., Social Mobility and Social Structure, NY: Cambridge University Press.

[22] Lin, N., Ensel, W. M. \& Vaughn, J. C. (1981a). "Social Resources and Occupational statusAttainment". Social Forces, 59: 11631181.

[23] Lin, N., Ensel, W. M. \&Vaughn, J. C. (1981b).Social Resources and Strength of Ties.American Sociological reviewVol:1046: pp. $393-405$.

[24] London, M., \&Stumpf, S. A. (1982). Managing Careers. Reading, MA: Addison-Wesley.

[25] Luthans, F., Hodgetts, R. M., \&Rosenkrantz, S. A. (1988). Real Managers. Cambridge, MA: Ballinger Publishing.

[26] Mehra, A., Kilduff, M.,\&Brass, D.J. (2001). The social networks of high and low self-monitors: Implications for workplace performance. Administrative Science Quarterly, 46(1),121-146.

[27] Noe, R.A. (1988). An Investigation of the Determinants of Successful Assigned Mentoring Relationships.Personnel Psychology, 41: $457-479$.

[28] Ng, T.W.H., Eby, L.T., Sorensen, K.L., \& Feldman, D.C. (2005). Predictors of objectiveandsubjective career success: A metaanalysis. Personnel Psychology, 58, 367-408.

[29] Podolny J. M., \& Baron, J. N. (1997). Resources and Relationships: Social Networks and Mobility in the Workplace.AmericanSociologicalReview, 62: 673-693.

[30] Pfeffer, J., Salancik, G. R., \&Leblibici, H. (1978). Uncertainty and social influence in organizational decision making. In M. W. Meyer (ed.). Environments and Organizations, San Francisco: Jossey- Bass.

[31] Podsakoff, P.M., MacKenzie, S.B., Lee, J.Y., \&Podsakoff, N.P. (2003). Common methodbiases in behavioral research: A critical review of the literature and recommendedremedies. Journal of AppliedPsychology, 88, 879-903.

[32] Sparrowe, R. T., \&Popielarz, P. A. (1995). Weak Ties and Structural Holes: The Effects of Network Structure on Careers. Paper Presented at the Academy of Management AnnualMeetings, Vancouver, BC.

[33] Turban, D. B. \& Dougherty, T. W. (1994). Role of ProtegePersonality in Receipt ofMentoring and Career Success.Academy of Management Journal, 37: 688-702.

[34] Wayne, S. J., Liden, R. C., Kraimer, M. L., \& Graf, I. K. (1999). The Role of HumanCapital, Motivation, and Supervisor Sponsorship to Career Success. Journal of Organizational Behavior, 20: 577-595.

[35] Yi-Ning Katherine Chen (2011) Social capital, Human capital, and Careersuccess in Publicrelations in Taiwan, Chinese Journal of Communication, 4:4, 430-449 